\title{
Sinetectula gen. nov., a new genus of Pisaniidae (Gastropoda: Buccinoidea) from the tropical Indian and Pacific Oceans
}

\author{
Koen FRAUSSEN ${ }^{1, *}$ \& Geerat J. VERMEIJ ${ }^{2}$ \\ ${ }^{1}$ Leuvensestraat 25, 3200 Aarschot, Belgium. Honorary Attaché and Research Associate, Institute of \\ Systematics, Evolution, Biodiversity (ISYEB), Muséum national d'histoire naturelle (MNHN), \\ CNRS, SU, EPHE, UA, CP 51, Paris, France. \\ ${ }^{2}$ Department of Earth and Planetary Sciences, University of California, Davis, \\ California 95616, USA. \\ ${ }^{*}$ Corresponding author: koen.fraussen@skynet.be \\ 2Email: gjvermeij@ucdavis.edu \\ ${ }^{1}$ urn:1sid:zoobank.org:author:5F9EFCF2-5BCF-486E-8D3E-088D85C45882 \\ ${ }^{2}$ urn:1sid:zoobank.org:author:14F57ADB-D930-4C52-AFCC-7B1F3248921E
}

\begin{abstract}
The genus Sinetectula gen. nov. is proposed to accommodate Triton egregius Reeve, 1844, Buccinum cinis Reeve, 1846, Buccinum nigricostatum Reeve, 1846, Buccinum (Pollia) farinosum Gould, 1850, Pisania naevosa Martens, 1880, Pollia shepstonensis Tomlin, 1926 and one still undescribed species. These species are discussed and compared, and remarks on their biogeography are provided. The occasional appearance of a labral denticle is recorded and the morphological variability of the group is discussed. The radula of $S$. egregius gen. et comb. nov. is described.
\end{abstract}

Keywords. Pisaniidae, Indian Ocean, Pacific, new genus.

Fraussen K. \& Vermeij G.J. 2021. Sinetectula gen. nov., a new genus of Pisaniidae (Gastropoda: Buccinoidea) from the tropical Indian and Pacific Oceans. European Journal of Taxonomy 748: 155-176. https://doi.org/10.5852/ejt.2021.748.1351

\section{Introduction}

The buccinoidean family Pisaniidae Gray, 1857 comprises a diverse clade of at least 230 known living species, distributed throughout the tropic and warm-temperate marine zones. About 100 of them are found in the Indo-West Pacific. Although the last 20 years have witnessed the description of many genera and numerous species in the family, both living and fossil, some groups remain taxonomically homeless or have been placed in heterogeneous catch-all genera such as Engina Gray, 1839.

One particular group of pisaniids that has long been recognized as requiring its own genus is a complex of at least seven species centered on Triton egregius Reeve, 1844 (Cernohorsky 1975: 191). These species have either been assigned to Engina Gray, 1839 in the broad sense (Cernohorsky 1975: 190191) or, in the case of Buccinum cinis Reeve, 1846, to Caducifer Dall, 1904 (Keen 1958: 398) or Monostiolum Dall, 1904 (Keen 1971:557-558). These assignments have been widely seen as provisional 
(Cernohorsky 1975: 191; Watters \& Finlay 1989: 48; Watters 2009: 266; Fraussen \& Rosado 2011: 77), but no assignment has yet been proposed. The presence of phenotypic variation and overlap among the genera Engina, Monostolium and Caducifer has caused much confusion and nomenclatural instability when assigning species to these taxa. Therefore, we here propose and discuss the new genus Sinetectula gen. nov. to accommodate the aforementioned species, with the aim to provide a more stable generic classification that can be used as a framework for future taxonomic and phylogenetic studies.

\section{Material and methods}

Empty shells of Pisaniidae, from the Cantharus group in particular, have been studied during visits to the collections of public institutes and those of private collectors. The present study is based on conchological morphology mainly, because molecular data are not yet available and shell characters are essential for the eventual recognition of fossil members. A specimen, with SEM photographs of its radula, was received from Yuri Kantor (IEE RAS).

Unless otherwise indicated, material from the French expeditions is deposited in the collections of the Muséum national d'histoire naturelle (MNHN), Paris, France. Apart from types, no individual catalogue numbers have been allocated, but lots are unambiguously designated and retrievable by the combination of expedition acronym and station number.

Bathymetric ranges are provided for each species, considering all the material and live-collected specimens only (when applicable), and are reported as the shallowest and deepest stations as explained by Bouchet et al. (2008).

The method of Verduin (1977) was employed to count the number of protoconch whorls.

\section{Institutional abbreviations}



\section{Other abbreviations}

$\mathrm{dd}=$ empty shell(s), dead collected

DW = Warén Dredge

$\mathrm{lv} \quad=$ live-collected specimen $(\mathrm{s})$

$\mathrm{PB}=$ Brushing Baskets

sh $=$ shell (uncertain whether alive or dead collected)

stn $=$ station 


\title{
Results
}

\author{
Phylum Mollusca Linnaeus, 1758 \\ Class Gastropoda Cuvier, 1795 \\ Subclass Caenogastropoda Cox, 1960 \\ Order Neogastropoda Wenz, 1938 \\ Superfamily Buccinoidea Rafinesque, 1815 \\ Family Pisaniidae Gray, 1857 \\ Genus Sinetectula gen. nov. \\ urn:lsid:zoobank.org:act:945AA942-8D54-4869-B958-3B8F14A46D02
}

\section{Type species}

Triton egregius Reeve, 1844.

\section{Diagnosis}

Shell small (maximum length to about $34 \mathrm{~mm}$ ), sturdy, fusiform, basally constricted; whorls weakly convex, separated by appressed suture; sculpture cancellate, dense, consisting of narrow but high spiral cords and fine axial ribs, spiral cords covered with obscure axial lamellae, spiral interspaces with fine secondary spiral threads or traces of them; subsutural sinus present; outer-lip edge serrated, evenly convex in profile, with fine lirae extending into aperture; parietal knob at the adapical end of the inner lip prominent, accentuating anal notch; columella with two adapical knobs; columellar callus expanded towards base and along siphonal canal, edge slightly flaring, surface sculptured with tiny knobs; siphonal canal open, dorsally weakly recurved.

Radula (only examined for Sinetectula egregia gen. et comb. nov.) (see Fig. 1Q) with tricuspid rachidian tooth; base rectangular, weakly arched; with minute cusps. Lateral teeth tricuspid; base protruding at inner side; outer cusp dominant, inner cusps close together, median cusp thin.

\section{Etymology}

Sinetectula gen. nov. is derived from the Latin 'sine', meaning 'without' in combination with 'tectula', meaning 'little roof', or, in other words, 'little homeless'. This also conjures up the contrast with the appearance of these small shelled gastropods that have, in reality, their home always with them. It also conjures up the contradiction that appears by virtue of the etymology by turning the 'little homeless' into 'not homeless', now that the name comes into existence.

\section{Included species}

Triton egregius Reeve, 1844, Buccinum cinis Reeve, 1846, Buccinum (Pollia) farinosum Gould, 1850, Pisania naevosa Martens, 1880, Buccinum nigricostatum Reeve, 1846 and Pollia shepstonensis Tomlin, 1926. In addition, we add one still undescribed species.

We did not study Tritonidea castanea Melvill, 1912 from the Persian Gulf or Pisania townsendi Melvill, 1918 from Pakistan, two species that share characteristics with Sinetectula gen. nov.

\section{Remarks}

Cernohorsky (1975: 191) tentatively placed Triton egregius and Buccinum (Pollia) farinosum, here assigned to Sinetectula gen. nov., in Engina. Species of Engina in the broad sense differ from Sinetectula gen. nov. in their usually broader shape with lower spire, denticles rather than lirae on the inner side of the outer lip, much weaker parietal (at the adapical end of the inner lip) and anal denticles and therefore a usually less obvious anal notch, the narrower columellar callus without flaring lip but with radial ridges on 
the parietal part of the columella, much broader and fewer spiral cords with much narrower interspaces, fewer and much broader axial ribs, and a straight or weakly convex (rather than convex) outer lip.

Species of Clivipollia Iredale, 1929 differ from Sinetectula gen. nov. in their larger protoconch consisting of $3 \frac{1}{2}$ to $3 \frac{3}{4}$ whorls, the fewer but much more prominent and more rounded axial ribs, the absence of a parietal denticle at the adapical end of the inner lip with a weaker but usually much broader anal notch, the well-defined outer-lip denticles that sometimes extend as lirae into the aperture, the broad and deep notch between the anal denticle and the outer-lip denticles and the usually more vivid colour (Fraussen \& Stahlschmidt 2016: 30-38).

The genus Engina differs from Sinetectula gen. nov. in its fewer but usually more prominent axial ribs, the usually stronger apertural sculpture with prominent knobs within the outer lip and radially orientated lirae on the columellar callus (instead of knobs). The radula of Engina turbinella Kiener, 1836, the type species of Engina (originally cited as Engina zonata Gray, 1839), looks similar to the radula of Sinetectula egregia gen. et comb. nov. but differs by the presence of 5 pronounced cusps on the rachidian tooth (Ponder 1972: 252, fig. 1-10).

The American genus Parviphos Sarasua, 1984 differs from Sinetectula gen. nov. in its strongly varicate outer lip, fewer axial ribs, and the more prominent parietal tooth at the adapical end of the inner lip (Watters 2009: 265-270, figs 232-262).

The American genus Monostiolum differs from Sinetectula gen. nov. in its axial sculpture reduced or absent on the last whorl, the weak apertural sculpture, and the absence of lirae within the outer lip. The spiral sculpture tends to be much finer in Monostiolum, and the spire is typically much higher, making for a slenderer shell (Watters 2009: 259-265, figs 197-223).

The East African genus Micrologus Fraussen \& Rosado, 2011 looks very similar in shape but differs from Sinetectula gen. nov. in its finer spiral sculpture with broader interspaces and a higher amount of secondary spiral cords (especially on the base and the transition to the siphonal canal), the much narrower columellar callus, the absence of knobs or lirae on the columellar callus and the absence of a serrated edge along the outer lip (Fraussen \& Rosado 2011: 76-78, figs 1-6).

The West Pacific genus Cancellopollia Vermeij \& Bouchet, 1998 looks similar but differs from Sinetectula gen. nov. in its smooth columellar callus, the stronger spiral sculpture without secondary spiral cords, the absence of a strong (bicarinate) subsutural cord and the stronger varix on the outer lip (Vermeij \& Bouchet 1998: 479).

When known, the protoconch of Sinetectula gen. nov. varies among species. In Sinetectula egregia gen. et comb. nov., it consists of $1 \frac{1}{4}$ flattened whorls lacking sculpture. In $S$. farinosa gen. et comb. nov., the protoconch consists of about $2-2 \frac{1}{2}$ whorls and bears a cord just above the abapical suture. In S. shepstonensis gen. et comb. nov., the protoconch consists of 3 whorls. The protoconch of $S$. cinis gen. et comb. nov. is unknown. The protoconch of $S$. farinosa gen. et comb. nov. resembles the planktotrophictype protoconch of species of Clivipollia by the presence of a subsutural spiral, but has fewer whorls (Fraussen \& Stahlschmidt 2016: 30-31, 36, figs 1a-b, 4j-1). The protoconch of S. shepstonensis gen. et comb. nov. resembles the planktotrophic-type protoconch of species of most Indo-West Pacific Engina by the number of whorls (3) and the rather conical shape. Species of Monostiolum and Parviphos have a smooth paucispiral protoconch (Watters \& Finlay 1989: 57, fig. 7; Watters 2009: 259, 265).

The genus Pisania Bivona, 1832 differs from Sinetectula gen. nov. in its much smoother, usually glossy shell wihout axial sculpture and the smoother aperture. The radula of Pisania striata (Gmelin, 1791), its type species (originally cited as Pisania striatula Bivona \& Bernardi, 1832), looks similar to the radula 
of Sinetectula egregia gen. et comb. nov. but differs by the presence of 5 more pronounced cusps on the rachidian tooth, the slightly shorter outer cusp on the lateral teeth and the absence of a protrusion at the inner margin of its base (Cernohorsky 1971: 138, fig. 17; Ponder 1972: 260, fig. 1-1).

As with the variation in protoconch morphology, shape and sculpture also vary quite considerably among species of Sinetectula gen. nov. This is not unusual within Pisaniidae, or Buccinidae Rafinesque, 1815 in the broad sense. Indeed, Sinetectula gen. nov. has a somewhat heterogenous appearance. The shape varies among the species, with an ovate shape of $S$. farinosa gen. et comb. nov., in contrast with the slender shape of $S$. egregia gen. et comb. nov. and others. The shape varies also within a single species, with slender and broad specimens occurring within, for example, $S$. cinis gen. et comb. nov. (according to their distribution, the broader ones from Galapagos, while the more slender ones usually from Costa Rica) and S. shepstonensis gen. et comb. nov. (the limited material we studied suggests a variation according to bathymetric distribution, if not latitudinal distribution: the slender ones from deeper water off Somalia, while the broad ones are from shallower water off Mozambique and South Africa). The convexity of the whorls is stable in all species except $S$. shepstonensis gen. et comb. nov., where the specimens with a broader shell have a more convex whorl compared to the slenderer specimens from deeper water. The sculpture is moderately constant within a single species. As a result, the differences between the species can be described in the strength of the spiral cords and the axial ribs as well as in their number.

\section{Distribution}

Sinetectula gen. nov. is known from the tropical Indo-West Pacific, from eastern Africa in the west to the American West Coast in the east. Yet, we have not detected any specimens or species from the Atlantic. Sinetectula gen. nov. joins the related genus Clivipollia in having representatives in both the Indo-West Pacific and tropical eastern Pacific. Shasky (1987: 30), and referred to by Skoglund (1992: 81), reported Clivipollia fragaria (Wood, 1828) from the western Pacific as well as from Isla del Coco, Costa Rica, where S. cinis gen. et comb. nov. also lives. While Pisania in the broad sense and Engina are distributed in all tropical seas (including the Atlantic and East Pacific), all living Sinetectula gen. nov. are, together with the Clivipollia group, as far as we know, restricted to the Indo-West Pacific.

Both Sinetectula farinosa gen. et comb. nov. and S. egregia gen. et comb. nov. have a wide range, reaching from eastern Africa to the Marshall Islands. These two species may have a similar mode of life, what is also reflected in the fact that both are syntopic at Kwajalein Atoll and in Western Samoa.

Sinetectula gen. nov. is so far not known from the fossil record. In the case of S. cinis gen. et comb. nov. and S. nigricostata gen. et comb. nov. it is likely that they, or their immediate ancestors, arrived in the eastern Pacific from the west no later than the Early Pleistocene (Vermeij 1987).

Sinetectula egregia (Reeve, 1844) gen. et comb. nov.

Figs 1-2, 10A-C

Triton egregius Reeve, 1844a: 119 (see Fig. 10A) (three syntypes in NHM(UK): BMNH-1967643, one of them figured by Cernohorsky 1975: 191, fig. 43).

Phos amoenus Schwengel, 1950: 81-82, pl. 5 fig. 4 (see Fig. 10B-C) (holotype in ANSP 186177).

Triton egregius - Reeve 1844b: pl. 18 fig. 78.

Engina egregia - Cernohorsky 1975: 191, fig. 43. — Singer \& Mienis 1995: 26-27. - Dekker \& Orlin 2000: 28.

Engina cf. egregia - Sharabati 1984: pl. 21 fig. 5.

Enzinopsis egregia - Dekker \& Gemert 2008: 129. 


\section{Type localities}

Triton egregius: "Island of Masbate, Philippines (found under stones at low water)".

Phos amoenus: Mbega Island, Fiji Islands.

\section{Material examined}

FRENCH POLYNESIA • 1 dd; Australes Archipelago, Port de Rurutu, BENTHAUS exped. stn DW2001; $22^{\circ} 27^{\prime} \mathrm{S}, 151^{\circ} 20^{\prime} \mathrm{W}$; depth 200-550 m; Nov. 2002; MNHN.

GUAM • 1 dd; Orote cliffs; 1978; KF 2164.

INDONESIA • 1 dd; Lombok, E of Gili Islands; depth 46 m; F. Lorenz leg.; Oct. 2002; KF $4004 \cdot 1$ dd; W of Tomia, Kaledupa reefs; depth 9-45 m; F. Lorenz leg.; Oct. 2001; KF $4106 \bullet 1$ lv; Alor Island, Kalabahi Harbour; depth 5-8 m; F. Lorenz leg.; Nov. 2002; KF 4107 • 1 lv; Sulawesi, near Pulau Raja; $1^{\circ} 08^{\prime} \mathrm{N}, 121^{\circ} 51^{\prime}$ E; depth 5-40 m; F. Lorenz leg.; Oct. 2003; KF 4854 (see Fig. 1I-L).

MARSHALL ISLANDS • 26 lv; Kwajalein, West Reef; depth 30-35 m; F. Lorenz leg.; 1989; KF 4817 • $1 \mathrm{lv}$; Kwajalein, in cave; depth 7-20 m; local collector leg.; KF 2163 • 20 lv; Kwajalein, oceanside of West Reef, in cave; depth 12 m; F. Lorenz leg.; 1989; KF 4756 (see Fig. 1A-H) • 1 lv; Majura Atoll, in cave; depth 1-2 m; local collector leg.; Jul. 1996; KF 2796.

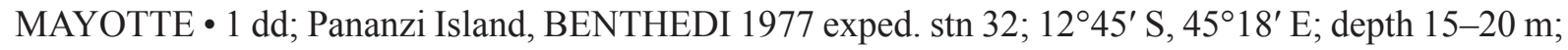
Mar. 1977; MNHN (see Fig. 1M-O).

PAPUA NEW GUINEA - 1 lv; Madang, Astrolabe Bay, PAPUA NIUGINI exped. PB14; $5^{\circ} 13.8^{\prime} \mathrm{S}$, 1454' E; depth 15 m; Nov. 2012; MNHN IM-2013-12540 (see Fig. 1P-Q).

SAMOA • 2 dd; western Samoa; KF 5277.

\section{Distribution}

Sinetectula egregia gen. et comb. nov. has a remarkably wide range, from eastern Africa (KF, MNHN) to India (Kurhe et al. 2014: 5, 10), along Indonesia (KF), Japan (Okutani 2000: 477, pl. 237 fig. 112) and Australia (Wilson 1994: 93, pl. 10 fig. 15) to the Australes Archipelago in French Polynesia (MNHN) and the Marshall Islands (KF).

We have not studied the specimens of Sinetectula egregia gen. et comb. nov. from the Red Sea reported on by Sharabati (1984: pl. 21 fig. 5) and referred to by Singer \& Mienis (1995: 26-27), Dekker \& Orlin (2000: 28) and Dekker \& Gemert (2008: 129), so cannot judge whether these records really belong to $S$. egregia gen. et comb. nov. or whether they belong to $S$. naevosa gen. et comb. nov. or both.

\section{Remarks}

Sinetectula egregia gen. et comb. nov. is recognisable by its characteristic colour pattern consisting of small dark brown spots situated in the space between the spiral cords where they cross the axial ribs. Occasionally, these spots are also present in the axial interspaces. These spots produce, when seen without magnification and, depending on their arrangement, a combination of moderately broad spiral bands ( 1 on the spire whorls and 2 on the body whorl) or dark axial blotches. This in combination with a rather rough sculpture dominated by 2 strong primary spiral cords on the spire whorls, gives the spire whorls a rather angular appearance. The colour on the spiral cords (white or pale) and spiral interspaces (usually darker) may inverse after crossing the prelabral varix, where, nearing the edge of the aperture, the spiral cords may become darker while the interspaces become paler or white (see Fig. 2C). 


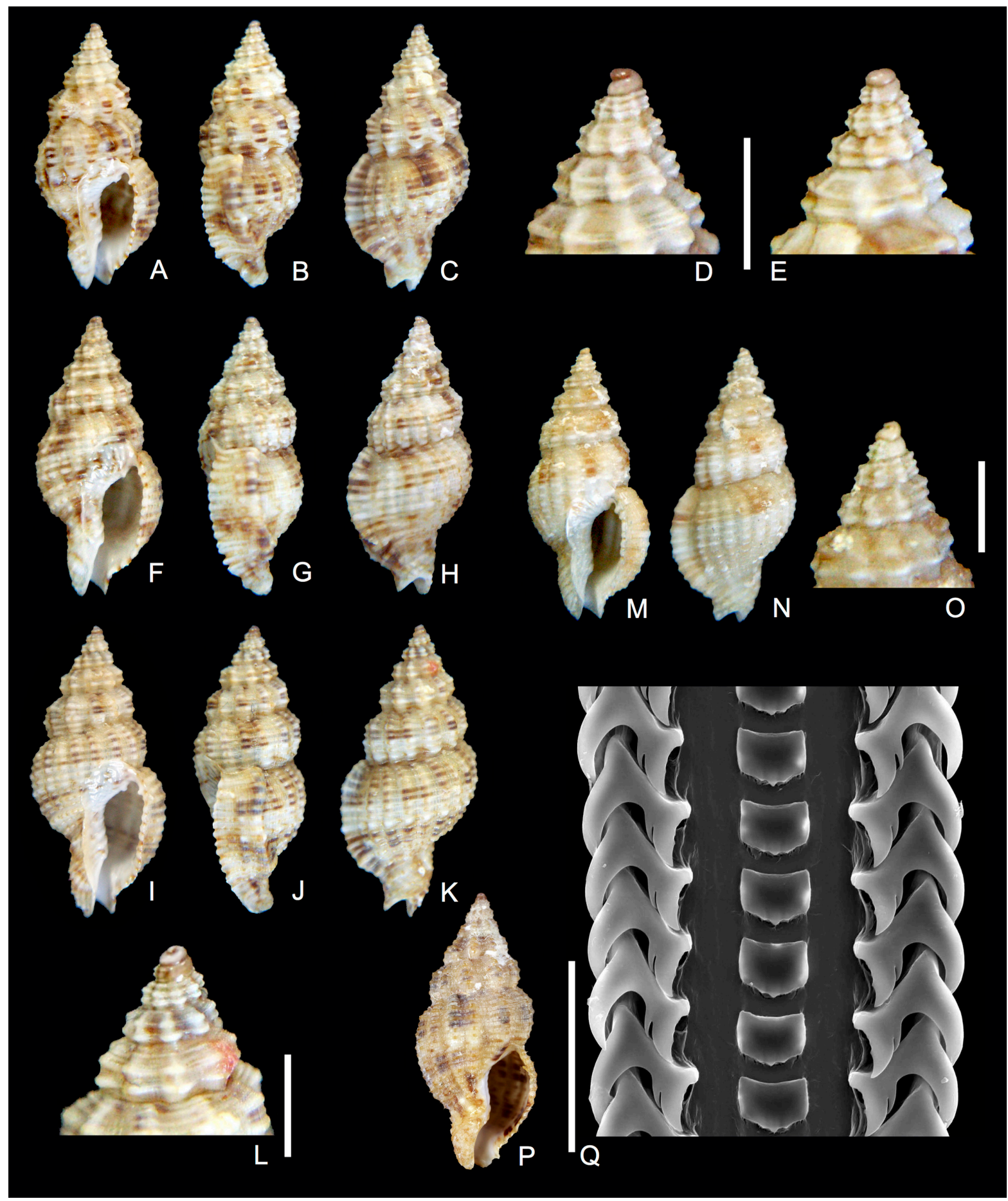

Fig. 1. Sinetectula egregia (Reeve, 1844) gen. et comb. nov. A-E. Specimen from the Marshall Islands, Kwajalein Atoll, in cave at Oceanside of West reef, depth $12 \mathrm{~m}, 12.0 \mathrm{~mm}$ long (KF 4756). F-H. Specimen with same collection data as for preceding, $14.5 \mathrm{~mm}$ long (KF 4756). I-L. Specimen from Indonesia, Sulawesi, $1^{\circ} 08^{\prime} \mathrm{N}, 121^{\circ} 51^{\prime} \mathrm{E}$, near Pulau Raja, depth 5-40 m, $16.9 \mathrm{~mm}$ long (KF 4854).

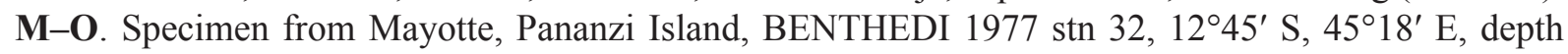
15-20 m, $15.0 \mathrm{~mm}$ long (MNHN). P. Specimen from Papua New Guinea, Madang, Astrolabe Bay, PAPUA NIUGINI stn PB14, 5⒔8' S, 1454ㅇ' E, depth 15 m, 16.6 mm long (MNHN IM-2013-12540). Q. Radula of preceding specimen. A-P. Images courtesy of MNHN - Alexandre Lardeur. Q. Image courtesy of Yuri Kantor. Scale bars: D-E, L, O =2.0 mm; Q = $100 \mu \mathrm{m}$. 

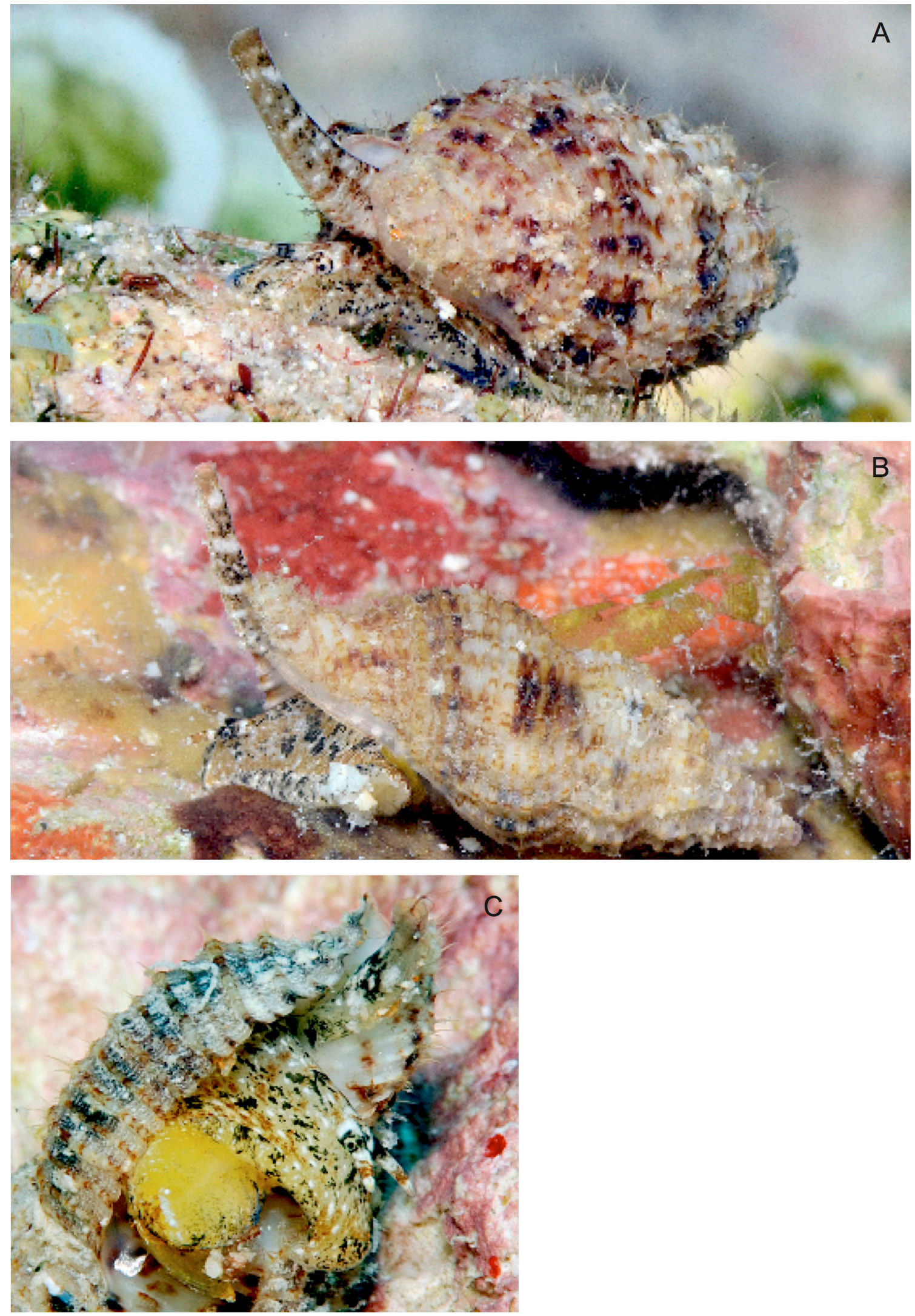

Fig. 2A-C. Sinetectula egregia (Reeve, 1844) gen. et comb. nov., in situ, Marshall Islands, Kwajalein Atoll, images courtesy of Jeanette Johnson, (C) 2015 In-Depth Images Kwajalein. 
The serrated edge of the outer lip deserves some closer study and is worth an extensive description. The protruding cusps are preceded by spiral interspaces while the notches are in the extension of the spiral cords. Specimens with an inversed pattern, as described in the previous paragraph, cause the optical illusion that the white spiral cords produce the white cusps (in reality it are the darker interspaces that lead the way to the white cusps).

The serrated edge shows quite some variation among the species as well as within some individuals. The spiral cords alternate between strong and slightly weaker: the original (primary) spiral cords already present on the upper spire whorls are slightly stronger than the (secondary) spiral cords that took shape along the antepenultimate whorl. As a consequence, the notch preceded by a stronger primary spiral cord is often slightly deeper than the notch preceded by a slightly weaker secondary spiral cord. This is more materialised along the basal (abapical) part of the lip (slightly above the transition from base to siphonal canal). As a result, the serrations may be arranged in pairs, causing a somewhat bilirate appearance.

The $12^{\text {th }}$ or $13^{\text {th }}$ cusp (counting from the suture) is often flanked by deeper and slightly broader notches and, as a result, accentuated (see Fig. 1B, G). We haven't detected any specimen where this accentuated cusp is also more protruding and surpassing the other cusps.

The protoconch is paucispiral, consisting of $1 \frac{1 / 4}{4}$ whorl with a rather flattened shape (see Fig. 1D-E, $\mathrm{O})$. The number of protoconch whorls is remarkably constant among all material we studied, with the exception of a single specimen from Sulawesi (KF 4854) that has $1 \frac{3 / 4}{4}$ protoconch whorls (see Fig. 1L). This shell is identical to other shells, including the shape of its protoconch, apart from the fact that the last protoconch whorl continues turning another half whorl. We counted the number of spiral cords according to the method of Verduin (1977). Other methods, for example following the suture in between the protoconch whorls, may be responsible for the 2 protoconch whorls counted in Phos amoenus by Schwengel (1950: 81). The slightly eroded apex of dead-collected but otherwise fresh looking specimens (for example KF 2164 from Guam) may have the sculpture along the first teleoconch whorl smoothened in such a subtle way that the protoconch appears larger and with more whorls.

In some specimens, the adapical apertural knob, inside the apertural lip, may be situated slightly more adapically than the parietal knob on the columella, resulting in a somewhat skewed anal notch, rather than having both anal knobs aligned.

For the description of the radula, we refer to the diagnosis under Sinetectula gen. nov. above.

Sinetectula naevosa gen. et comb. nov. differs from S. egregia gen. et comb. nov. by its larger protoconch ( $0.9 \mathrm{~mm}$ long and $0.9 \mathrm{~mm}$ in diameter (KF 5029) vs 0.6 to $0.7 \mathrm{~mm}$ long and 0.7 to $0.8 \mathrm{~mm}$ in diameter in S. egregia gen. et comb. nov.), the slightly higher number of protoconch whorls ( $1 \frac{1}{2}$ instead of usually $\left.1 \frac{1}{4}\right)$, the upper spire whorls that are higher and increase in size more quickly, resulting in a slenderer spire (whereas in $S$. naevosa gen. et comb. nov. the transition from $3^{\text {rd }}$ to $4^{\text {th }}$ whorl falls within the first $5 \mathrm{~mm}$ of the teleoconch length, in S. egregia gen. et comb. nov. this occurs from the $4^{\text {th }}$ to $5^{\text {th }}$ whorl that falls within these first $5 \mathrm{~mm}$ ). The spiral sculpture of $S$. naevosa gen. et comb. nov. is finer, starting with 3 finer primary spiral cords on the first teleoconch whorls (instead of 2 dominant ones), resulting in a more convex shape of the upper spire whorls. The secondary spiral cords, to the contrary, are slightly stronger when situated in the center between the primary spiral interspaces in $S$. naevosa gen. et comb. nov. but lower in number (1 to 3 vs 4 or 5 in $S$. egregia gen. et comb. nov.). By contrast, the number of secondary spiral cords on the subsutural slope is higher in number in $S$. naevosa gen. et comb. nov. The axial ribs are weaker but slightly higher in number, especially on the spire whorls.

Sinetectula farinosa gen. et comb. nov. differs from S. egregia gen. et comb. nov. by its higher number of protoconch whorls, the much broader shape with shorter spire and slightly more convex whorls, 
the more cancellate sculpture with stronger spiral cords and axial ribs that are covered by pronounced incremental lamellae, sharper denticles on the columella and fewer (5 to 8) but stronger knobs inside the outer lip.

Sinetectula cinis (Reeve, 1846) gen. et comb. nov.

Figs 3, 10D-E

Buccinum cinis Reeve, 1846: [1], plate 11 no. 84 (see Fig. 10D) (type(s) not traced).

Caducifer? thaleia Pilsbry \& Lowe, 1932: 67, pl. 6 fig. 6 (see Fig. 10E) (one syntype in ANSP 81972).

Pisania cinis - Tryon 1881: 147, pl. 71 fig. 204.

Caducifer (Monostiolum) cinis - Keen 1971: 557-558, no. 1100.

\section{Type localities}

Buccinum cinis: Galápagos Archipelago, "Gallapagos [sic] Islands (under stones)”. Caducifer? thaleia: Costa Rica, Cocos Island.

\section{Material examined}

Syntype

COSTA RICA -1 sh, type of $C$. thaleia; Cocos Island; $5^{\circ} 32^{\prime}$ N, $87^{\circ} 04^{\prime}$ W; R.E. Snodgrass leg.; Jul. 1899; ANSP 81972.

\section{Other material}

COSTA RICA • 1 lv; Cocos Island, Dos Amigos; 2010; KF 1013 (see Fig. 3E-H) • 6 additional lots (not specified); Cocos Island; SBMNH.

GALAPAGOS • 1 sh; Santa Cruz Island, Academy Bay; AMNH 110439 • 1 sh; Santa Cruz Island, Academy Bay, under rocks in tide pool; USNM 812823 - 1 sh; north of Santa Cruz Island, under rocks at low tide; USNM 824680 • 1 sh; Hood Island; AMNH 89659 • 1 sh; Rabida Island; AMNH 111853 • 2 sh; San Cristóbal Island; SBMNH 24676 • 1 sh; Isla Baltra, at low tide under rocks; USNM 678930 • 1 lv; IslaFernandina, under rocks; depth 10-15 m;NMR 94140 • 1 sh; "Galápagos Islands"; USNM 171968 • 1 sh; "Galápagos Islands"; LACM 120909 • 1 lv; Isla Baltra, between rocks and rubble; depth 3-4 m; KF 2123 (see Fig. 3A-D) • 2 lv; Santa Cruz Island, trawled; depth 30 m; KF 7466.

\section{Distribution}

Sinetectula cinis gen. et comb. nov. is restricted to the central eastern Pacific. We studied specimens from Costa Rica and Galápagos. López-Pérez (2013) recorded the species from Mexico. We have not studied the material from Mexico preserved in SBMNH or the material from Colombia preserved in UV.

\section{Remarks}

Sinetectula cinis gen. et comb. nov. merits special attention because of the presence of a distinct labral tooth. The tooth, first noted by Vermeij $(2001: 464,475,497)$, is the eighth (counting from the suture) of 13 outer-lip serrations (without counting along the siphonal canal) formed as an enlarged and protruding space between external spiral cords. A single specimen (KF 2123) has an additional weak tooth formed by the seventh outer-lip serration (see Fig. 3D).

Only Sinetectula nigricostata gen. et comb. nov. has, occasionally, a similar labral tooth, but no comparable labral tooth is found among members of such related genera as Bailya M. Smith, 1944, 
Caducifer, Clivipollia, Dianthiphos Watters, 2009, Jeannea Iredale, 1912, Monostiolum, Parabailya Watters \& Finlay, 1989, Parviphos or Speccapollia Fraussen \& Stahlschmidt, 2016.

At a maximum length of $34.5 \mathrm{~mm}$ (Simon Aiken: pers. com. 2020), S. cinis gen. et comb. nov. is also the largest member of this genus. This exceptional size could be related to the high planktonic productivity of the waters around the Galápagos Islands. Other species of the genus are smaller and they usually live in reef environments where planktonic productivity tends to be low.

We follow Keen (1958: 398, 1971: 557-558) and consider Caducifer? thaleia to be a subjective junior synonym of $S$. cinis gen. et comb. nov. The type specimen (ANSP 81972), from Cocos Island, has a damaged outer lip and therefore does not show a labral tooth; but specimens from Cocos Island (SBMNH) with an intact outer lip do express a labral tooth. Specimens from Costa Rica are not obviously different from typical S. cinis gen. et comb. nov. from the Galápagos Islands, apart from the usually somewhat slenderer shape.

Sinetectula shepstonensis gen. et comb. nov., a species from eastern Africa with an almost identical sculpture, differs from $S$. cinis gen. et comb. nov. in its more equally sculptured outer lip without labral denticle, the slightly finer spiral sculpture with fine secondary spiral cords, the more convex whorls and the weakly constricted base resulting in a slightly narrower siphonal canal.

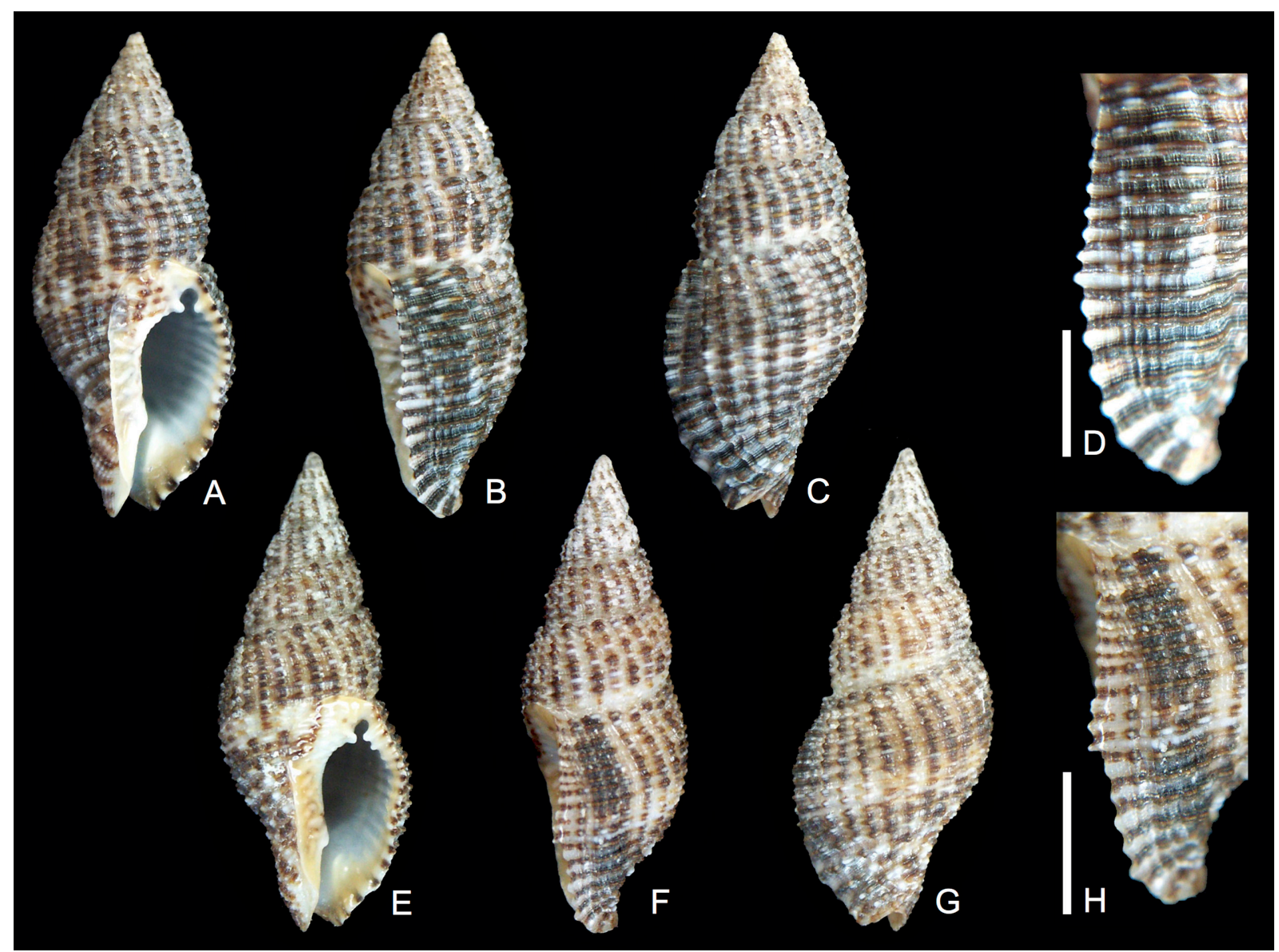

Fig. 3. Sinetectua cinis (Reeve, 1846) gen. et comb. nov. A-D. Specimen from Galápagos, Isla Baltra, depth 3-4 m, 31.0 mm long (KF 2123). E-H. Specimen from Costa Rica, Cocos Island, Dos Amigos, depth 25-30 m, $29.3 \mathrm{~mm}$ long (KF 1013). Scale bars: $5.0 \mathrm{~mm}$. 
Sinetectula nigricostata gen. et comb. nov. is the second member of the genus that has an apparent labral denticle. It differs from $S$. cinis gen. et comb. nov. in its convex whorls, the broader shape with a shorter spire, the finer spiral sculpture, the stronger axial ribs that are lower in number, the weak or absent incremental lamellae, the constricted base with longer siphonal canal, the pattern consisting of fine spiral lines and the smaller adult size.

Sinetectula farinosa (Gould, 1850) gen. et comb. nov.

Figs $4-5,10 \mathrm{~F}-\mathrm{G}$

Buccinum (Pollia) farinosum Gould, 1850: 152-153 (holotype in USNM 5719, figured by Cernohorsky 1975: 190, fig. 40).

Hindsia angicostata Pease, 1860: 142 (lectotype and one paralectotype in NHM(UK): BMNH-1961159 and 1961160).

Hindsia angicostata - Kay 1965: 16-17, pl. 1 figs 15-16 (see Fig. 10f-g).

Engina farinosa - Cernohorsky 1975: 190, figs 40-42. — Robin 2008: pl. 189 fig. 10.

Cantharus farinosus - Kay 1979: 261, figs 91e-f, 92d.

\section{Type localities}

Buccinum (Pollia) farinosum: Hawaii, "Sandwich Islands, Kauai".

Hindsia angicostata: "Sandwich Islands".

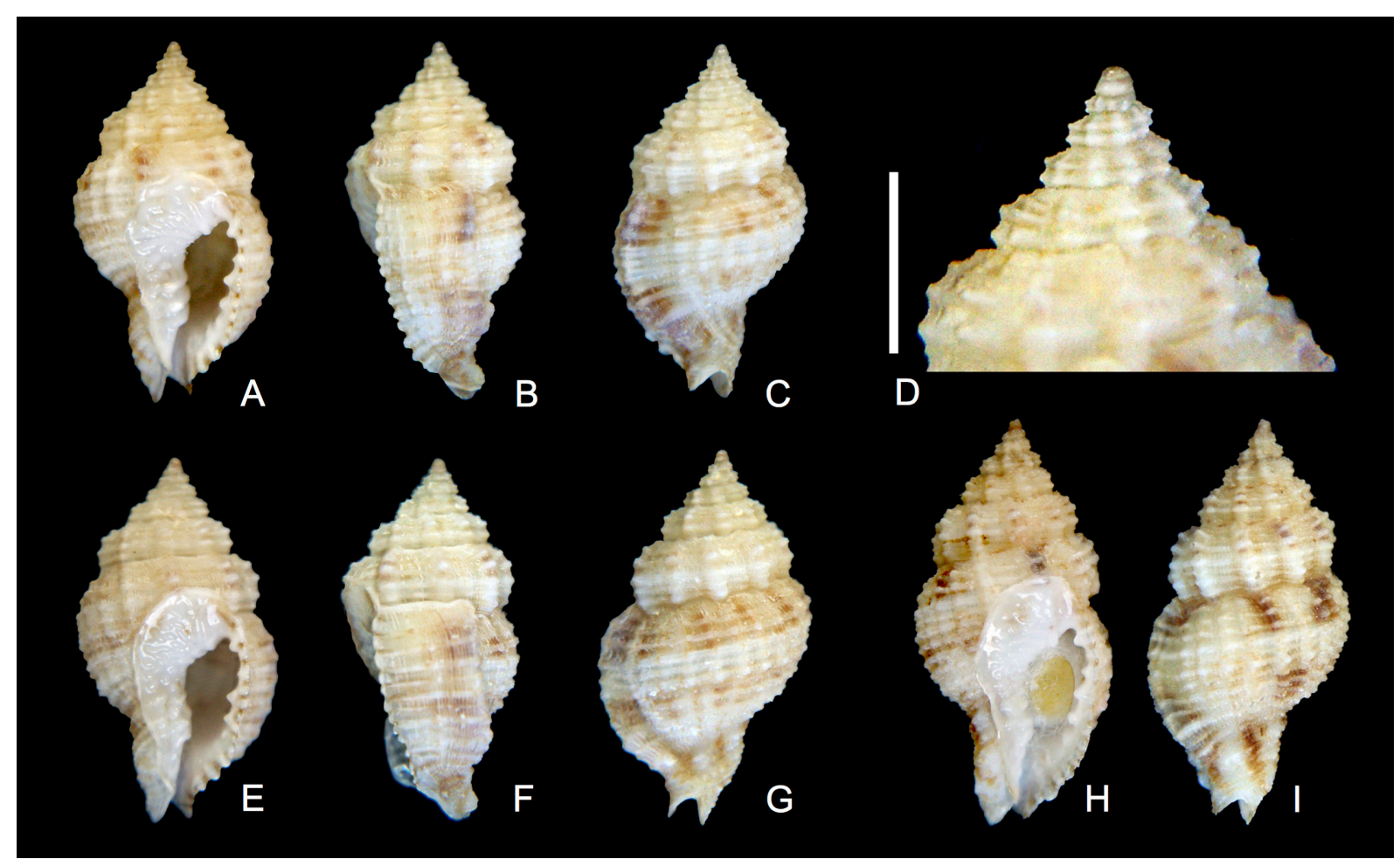

Fig. 4. Sinetectula farinosa (Gould, 1850) gen. et comb. nov. A-D. Specimen from the Marshall Islands, Kwajalein Atoll, in cave at Oceanside of West reef, depth $12 \mathrm{~m}, 14.6 \mathrm{~mm}$ long (KF 4766). E-G. Specimen with same collection data as for preceding, $15.6 \mathrm{~mm}$ long (KF 4766). H-I. Specimen from Mozambique, Fernao Velosa Bay, depth 3-4 m, $18.6 \mathrm{~mm}$ long (KF 5378). Scale bar: $2.0 \mathrm{~mm}$. 


\section{Material examined}

MARSHALL ISLANDS • 12 lv; Kwajalein, West Reef; depth 30-35; F. Lorenz leg.; 1989; KF 4757 • 7 dd; Kwajalein, ocean side of West Reef, in cave; depth 12 m; F. Lorenz leg.; 1989; KF 4765 • 19 dd; Kwajalein, ocean side of West Reef, in cave; depth 12 m; F. Lorenz leg.; 1991; KF 4766 (see Fig. 4A-G).

MOZAMBIQUE • 2 lv; Fernao Veloso Bay; depth 3-4 m; J. Rosado leg.; KF 5378 (see Fig. 4H-I) • 1 dd; "Mozambique"; KF 5031.

SAMOA 11 lv; western Samoa; KF 5276.
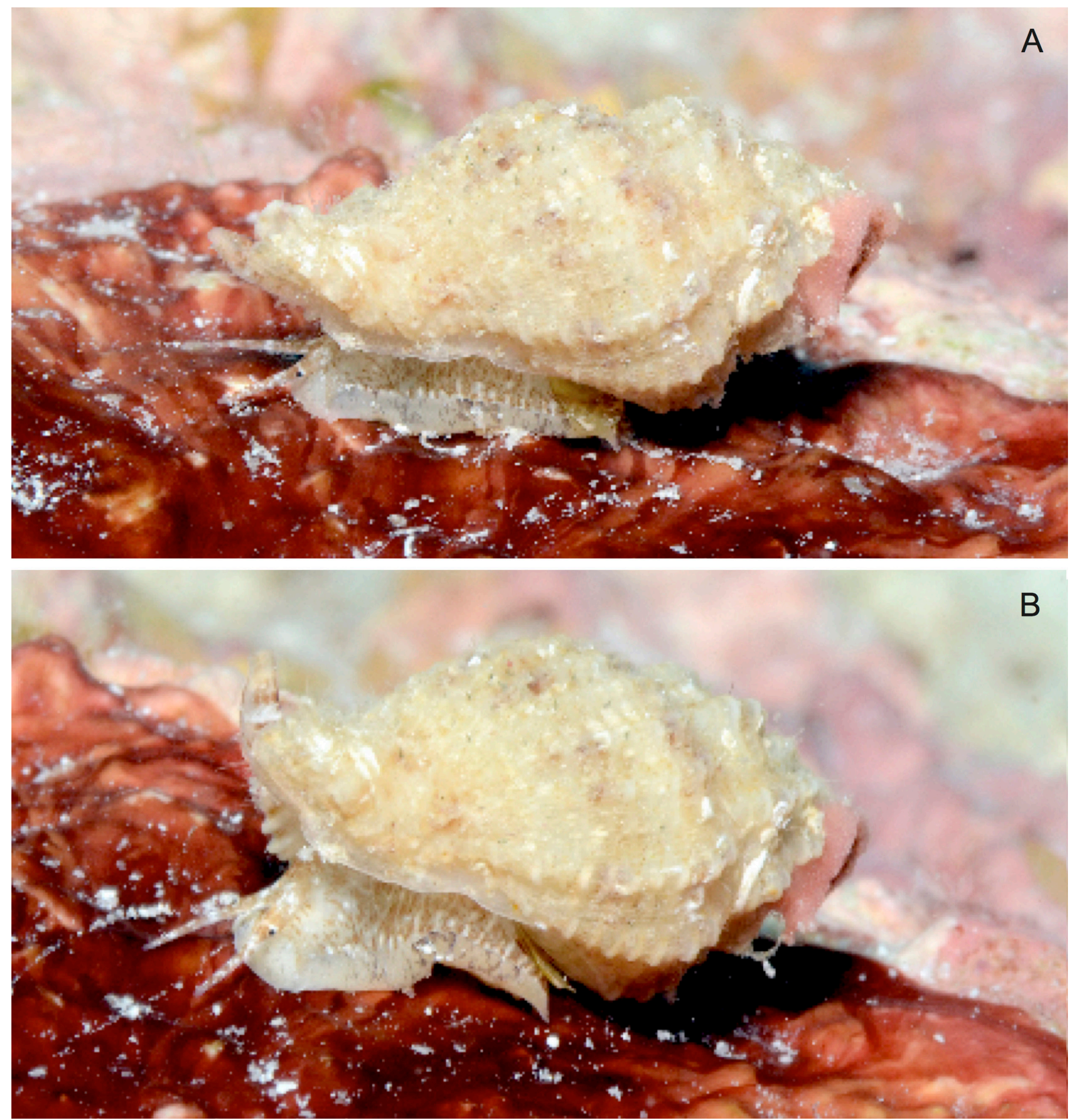

Fig. 5A-B. Sinetectula farinosa (Gould, 1850) gen. et comb. nov., in situ, Marshall Islands, Kwajalein Atoll, images courtesy of Jeanette Johnson, (C) 2015 In-Depth Images Kwajalein. 


\section{Distribution}

Sinetectula farinosa gen. et comb. nov. has a remarkably wide range, from eastern Africa (KF) to Japan (Okutani 2000: 477, pl. 237 fig. 113, as Hindsia nivea), Hawaii (Pease 1860: 142) and the Marshall Islands (KF).

\section{Remarks}

Sinetectula farinosa gen. et comb. nov. is recognisable by its broad, ovate shell in combination with a rather cancellate sculpture.

The furrowed edge of the labral lip is typical of the genus, very similar in shape to $S$. egregia, with a similar tendency to arrange the cusps in pairs, but the slightly deeper basal notches accentuate the basal cusp much less (see Fig. 4B, F).

The protoconch is multispiral, consisting of 2 to $2 \frac{1}{2}$ whorls, the last whorl with a tiny suprasutural spiral keel (see Fig. 4D).

Sinetectula egregia gen. et comb. nov. differs from $S$. farinosa gen. et comb. nov. by its lower number of protoconch whorls ( 1 vs 2 to $\left.2^{1 / 2}\right)$, the slender shape with a higher spire, the weaker sculpture with finer spiral cords and finer axial ribs, the weaker denticles on the columella and the higher number (usually 12) but weaker knobs inside the outer lip.

Sinetectula naevosa (Martens, 1880) gen. et comb. nov.

Figs $6,10 \mathrm{H}-\mathrm{Q}$

Pisania naevosa Martens, 1880: 240, pl. 20 fig. 8 (see Fig. 10H).

Engina egregia - Kilburn et al. 2010: 41, unnumbered fig.

\section{Type locality}

Mauritius.

\section{Material examined}

Syntypes

MAURITIUS • 4 dd; MFN ZMB/Moll-22029 mfn-e4d800 (see Fig. 10I-Q).

\section{Other material}

MOZAMBIQUE • 1 dd; “off Mozambique”; local collector; KF 5029 (see Fig. 6).

SOUTH AFRICA • 3 lv; Natal, Richards Bay; local collector; KDM.

\section{Distribution}

Sinetectula naevosa gen. et comb. nov. is an overlooked species, the few records we found being under former combinations of $S$. egregia gen. et comb. nov. from along the eastern African coast. The species is known from Mauritius (type locality) and we could confirm records from South Africa in the south and Somalia in the north. Further study may reveal a much wider range. 


\section{Remarks}

We studied a limited number of specimens of Sinetectula naevosa gen. et comb. nov. and, therefore, we are not able to discuss the variability within the species. These shells conform to the original description, especially the characteristic number of spiral cords and axial ribs as well as the well-defined anal notch.

The shells differ from Sinetectula egregia gen. et comb. nov. by the larger protoconch $(0.9 \mathrm{~mm}$ long and $0.9 \mathrm{~mm}$ in diameter (KF 5029) vs 0.6 to $0.7 \mathrm{~mm}$ long and 0.7 to $0.8 \mathrm{~mm}$ in diameter in S. egregia gen. et comb. nov.), in combination with a smaller teleoconch size, the slightly higher number of protoconch whorls $\left(1 \frac{1}{2}\right.$, instead of usually $\left.1 \frac{1}{4}\right)$, the upper spire whorls that are higher and increase in size more quickly, resulting in a slenderer spire. Whereas in $S$. naevosa gen. et comb. nov. the transition from $3^{\text {rd }}$ to $4^{\text {th }}$ whorl falls within the first $5 \mathrm{~mm}$ of the teleoconch length, in $S$. egregia gen. et comb. nov. it is the transition from $4^{\text {th }}$ to $5^{\text {th }}$ whorl that falls within these first $5 \mathrm{~mm}$. The spiral sculpture of $S$. naevosa gen. et comb. nov. is finer, starting with 3 finer primary spiral cords along the first teleoconch whorls (instead of 2 dominant ones), resulting in a more convex shape of the upper spire whorls. The secondary spiral cords, to the contrary, are slightly stronger when situated in the center between the primary spiral interspaces in $S$. naevosa gen. et comb. nov. but lower in number (1 to 3 vs 4 or 5 in $S$. egregia gen. et comb. nov.). Also, the axial ribs in S. egregia gen. et comb. nov. are weaker and lower in number. The brown pattern of $S$. naevosa gen. et comb. nov. appears to be more evenly arranged along slightly narrower spiral bands than is the case in $S$. egregia gen. et comb. nov.



Fig. 6A-E. Sinetectula naevosa (Martens, 1880) gen. et comb. nov., off Mozambique, $15.0 \mathrm{~mm}$ long (KF 5029). Scale bars: $2.0 \mathrm{~mm}$. 
Sinetectula nigricostata (Reeve, 1846) gen. et comb. nov.

Figs $7,10 \mathrm{R}$

Buccinum nigricostatum Reeve, 1846: [1], pl. 10 fig. 73 (see Fig. 10R) (type(s) not traced).

Parviphos nigricostatus - Watters 2009: 266.

\section{Type locality}

"Panama (under stones at low water)".

\section{Material examined}

PANAMA • 2 lv; Gulf of Chiriqui, off Canal of Afuera; depth 70-80 m; 1989; KF $0533 \bullet 1$ lv; Gobernadora Island, at low tide; KF 3378 (see Fig. 7A-D).

\section{Distribution}

Sinetectula nigricostata gen. et comb. nov. is restricted to the central eastern Pacific. Known from Panama.

\section{Remarks}

Sinetectula nigricostata gen. et comb. nov. is charactarised by the convex whorls and fine spiral sculpture in combination with a peculiar pattern consisting of well-defined spiral lines. S. nigricostata gen. et comb. nov. is the only member of the genus that shares with $S$. cinis gen. et comb. nov. the presence of a labral denticle (see Fig. 7D). The labral denticle is usually situated at the $7^{\text {th }}$ (vs $8^{\text {th }}$ in $S$. cinis gen. et comb. nov.) spiral interspace. Depending on the strength of the secondary spiral cords, the first interspace may be counted double in the case that it is divided by a secondary spiral cord that has become as strong as the primary spiral cords, thus with the labral denticle appearing in the $8^{\text {th }}$ interspace.

Sinetectula cinis gen. et comb. nov. differs from S. nigricostata gen. et comb. nov. in its laterally more flattened spire (instead of convex whorls), the broader spiral cords, the weaker axial ribs that are higher in number, the stretched base (instead of constricted) with a shorter siphonal canal, a less defined pattern of lines, and the slightly larger adult size.

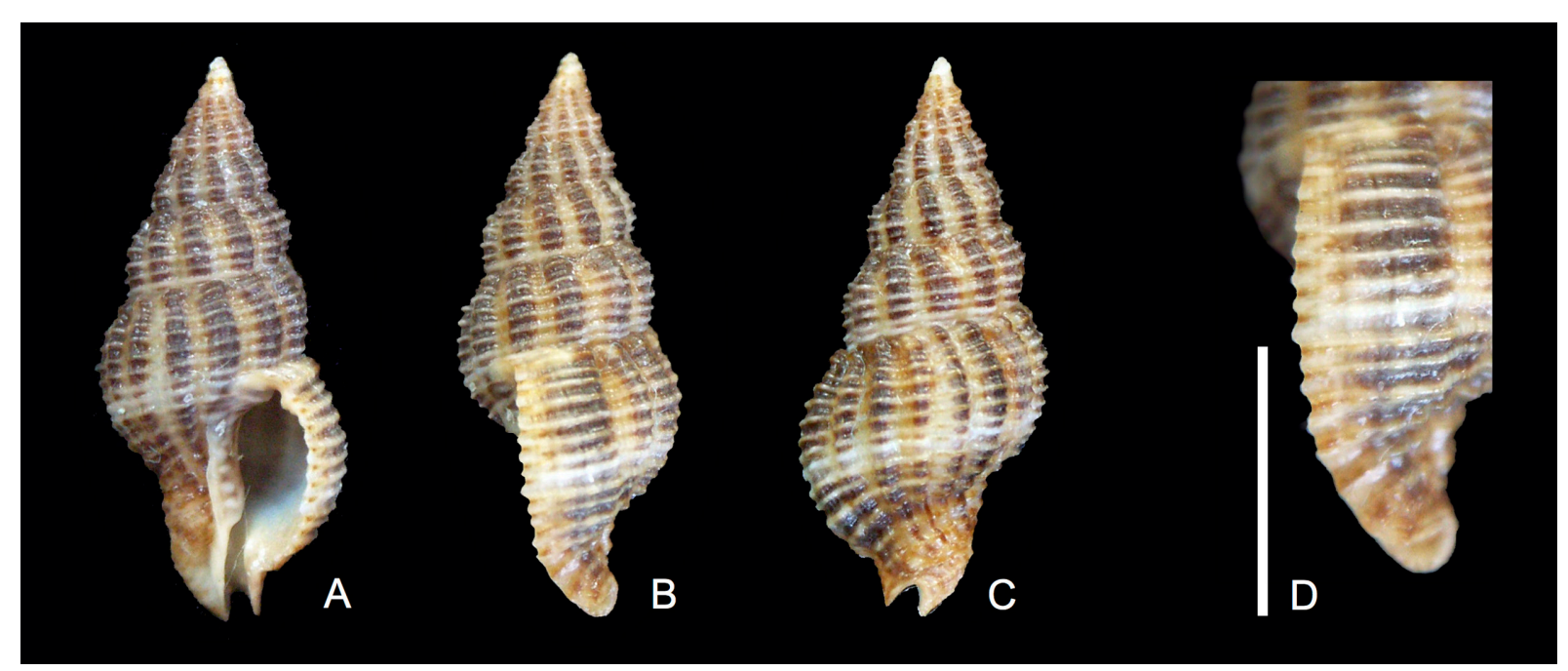

Fig. 7A-D. Sinetectula nigricostata (Reeve, 1846) gen. et comb. nov., Panama, Gobernadora, low tide, $19.6 \mathrm{~mm}$ long (KF 3378). Scale bar: $5 \mathrm{~mm}$. 
Sinetectula shepstonensis (Tomlin, 1926) gen. et comb. nov.

Figs 8, 10S-T

Pollia shepstonensis Tomlin, 1926: 291, pl. 16 fig. 4 (see Fig. 10S).

Cantharus (Prodotia) shepstonensis - Cernohorsky 1975: 203, fig. 63.

Prodotia shepstonensis - Kilburn et al. 2010: 52, unnumbered fig.

Type locality

"Beach End near Port Shepstone".

Material examined

Holotype

SOUTH AFRICA • 1 dd; Kwazulu-Natal Coast, Port Shepstone; NHM(UK) 1926.12.6.6 (see Fig. 10T).

Other material

OMAN • 3 lv; Mirbat; depth 30 m; J. Rosado leg.; Nov. 2016; KF 8048 (see Fig. 8A-B).

SOMALIA • 1 dd; "Somalia"; KF 1627 • 2 dd; off Somalia, deep water; KF 2208 (see Fig. 8C-G).

\section{Distribution}

Sinetectula shepstonensis gen. et comb. nov. is known from South Africa in the south, along Somalia to Oman in the north.

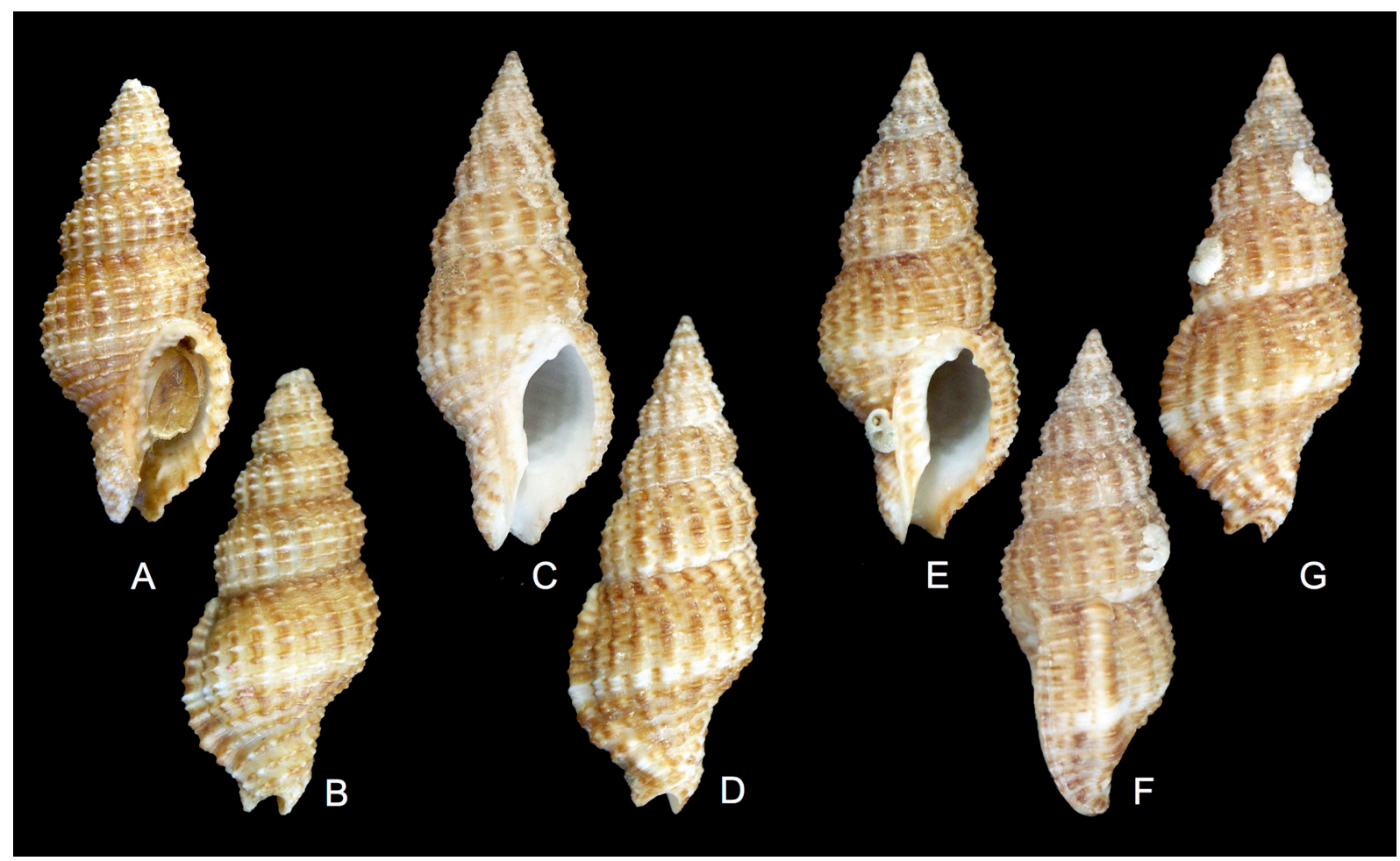

Fig. 8. Sinetectula shepstonensis (Tomlin, 1926) gen. et comb. nov. A-B. Specimen from Oman, Mirbat, depth $30 \mathrm{~m}, 24.9 \mathrm{~mm}$ long (KF 8048). C-D. Specimen from off Somalia, deep water, $25.0 \mathrm{~mm}$ long (KF 2208). E-G. Specimen with same collection data as for preceding, $27.3 \mathrm{~mm}$ long (KF 2208). 


\section{Remarks}

Sinetectula shepstonensis gen. et comb. nov. shares all characteristics with S. cinis gen. et comb. nov., apart from the presence of a labral denticle. Specimens from deep water (see Fig. 9C-G) are more slender, with a laterally more flattened spire very similar to S. cinis gen. et comb. nov.; shallow water specimens have slightly more convex whorls. One of the specimens has the apex in rather good condition without too much erosion and shows a conical, rather high, multispiral protoconch consisting of 3 whorls with a small tip.

Sinetectula cinis gen. et comb. nov. is almost identical in sculpture but differs from S. shepstonensis gen. et comb. nov. in its rougher sculptured edge of the outer lip with a labral denticle, the slightly stronger spiral sculpture in combination with much weaker secondary spiral cords, the laterally weakly flattened whorls (instead of convex), the slightly stretched base (instead of constricted) resulting in a slightly broader siphonal canal and a much darker colour.

Sinetectula nigricostata gen. et comb. nov. looks similar to but differs from $S$. shepstonensis gen. et comb. nov. in its slightly more convex whorls, the slightly finer spiral sculpture, the stronger axial ribs that are lower in number, the constricted base with longer siphonal canal and a much darker pattern consisting of fine spiral lines.

Sinetectula gen. nov., sp. non descr.

Fig. 9

\section{Material examined}

INDONESIA • 1 dd; S Sulawesi, about 37 km (20 nautic miles) NW of Makassar, Tengga Tengga Reef; 452'62" S, 11907'65" E; depth 37 m; F. Lorenz leg.; Oct. 2002; KF 4863.

\section{Remarks}

The single, subadult shell we studied looks like a slender $S$. nigricostata gen. et comb. nov. but with the protoconch of $S$. egregia gen. et comb. nov. It differs from $S$. nigricostata gen. et comb. nov. by its larger protoconch and the slenderer shell. It differs from S. egregia gen. et comb. nov. by the different shape, sculpture and entirely different colour pattern.

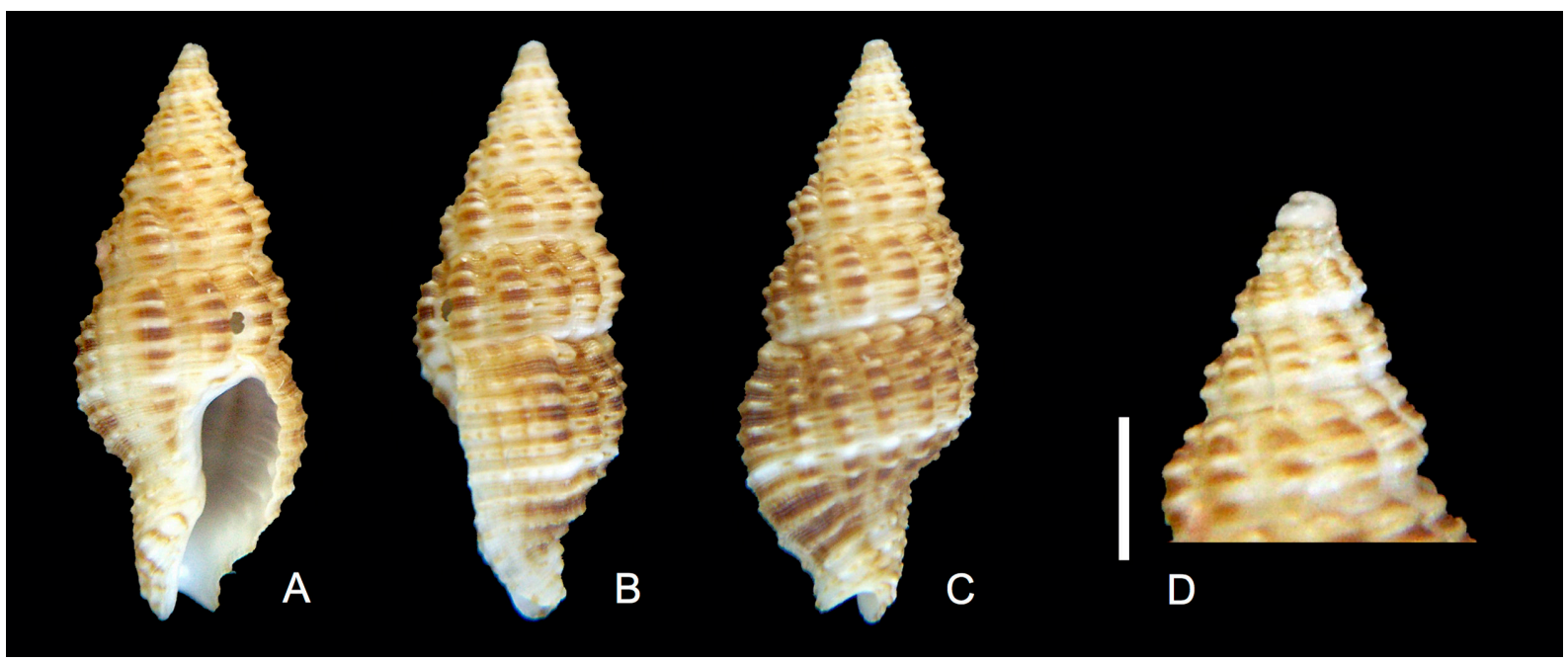

Fig. 9A-D. Sinetectula gen. nov., sp. non descr. Specimen from Indonesia, S Sulawesi, about $37 \mathrm{~km}$ (20 nautic miles) NW of Makassar, $4^{\circ} 52^{\prime} 62^{\prime \prime} \mathrm{S}, 119^{\circ} 07^{\prime} 65^{\prime \prime} \mathrm{E}$, near a steel wreck at Tengga Tengga Reef, depth $10 \mathrm{~m}, 16.6 \mathrm{~mm}$ long (KF 4863). Scale bar: $2 \mathrm{~mm}$. 

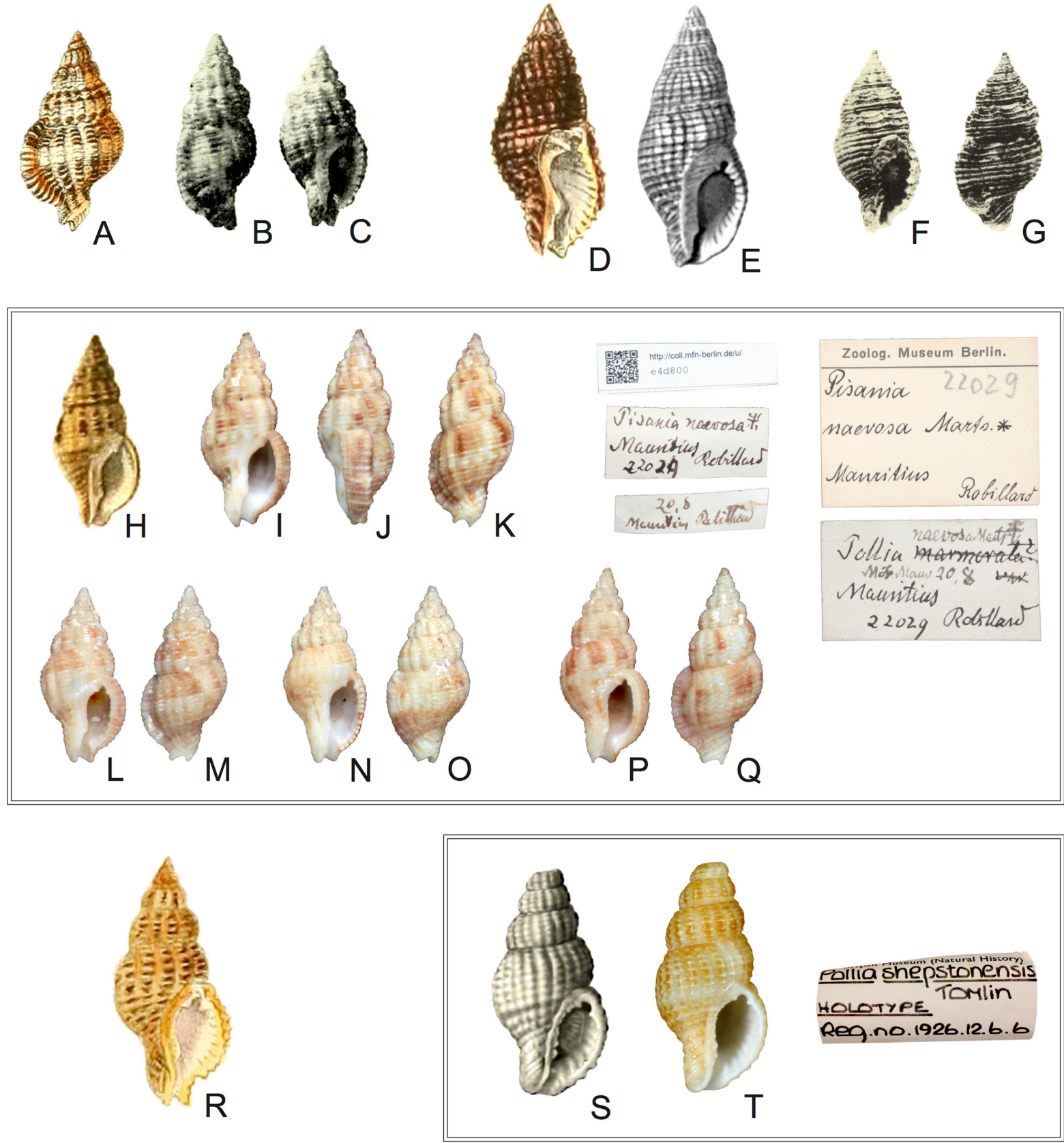

Fig. 10. Original figures and types. A. Syntype of Triton egregius Reeve, 1844, original figure taken from Reeve (1844b: pl. 18 fig. 78). B-C. Types of Phos amoenus Schwengel, 1950, taken from Schwengel (1950: pl. 5 fig. 4). B. Holotype, $15 \mathrm{~mm}$ long. C. Paratype, 13-14 mm long. D. Type of Buccinum cinis Reeve, 1846, original figure taken from Reeve (1846: pl. 11 no. 84). E. Syntype of Caducifer? thaleia Pilsbry \& Lowe, 1932, original figure taken from Pilsbry \& Lowe (1932: pl. 6 fig. 6), $26.3 \mathrm{~mm}$ long. F-G. Lectotype of Hindsia angicostata Pease, 1860, taken from Kay (1965: pl. 1; figs 15-16), $15.5 \mathrm{~mm}$ long. H. Syntype of Pisania naevosa Martens, 1880, original figure taken from Martens (1880: pl. 20 fig. 8), 16 mm long. I-Q. Syntypes of Pisania naevosa Martens, 1880, MFN, ZMB/Moll-22029, images courtesy of Christine Zorn, Berlin. I-K. $16.3 \mathrm{~mm}$ long. L-M. $15.1 \mathrm{~mm}$ long. N-O. $14.9 \mathrm{~mm}$ long. P-Q. $16.3 \mathrm{~mm}$ long. R. Type of Buccinum nigricostatum Reeve, 1846, original figure taken from Reeve (1846: pl. 10 fig. 73). S. Holotype of Pollia shepstonensis Tomlin, 1926, original figure taken from Tomlin (1926: pl. 16 fig. 4), 24 mm long. T. Holotype of Pollia shepstonensis Tomlin, 1926, NHM(UK) 1926.12.6.6, image courtesy of Yves Terryn, $24 \mathrm{~mm}$ long. 


\section{Discussion}

The species that we accommodate within Sinetectula gen. nov. may look quite heterogeneous with respect to shape and colour pattern, and not all species look representative for the genus. This was already reflected in their former, provisional placements in a number of different genera. To our advantage, $S$. egregia gen. et comb. nov. and S. farinosa gen. et comb. nov. form a well recognizable duo, but with a contrasting shape and protoconch, corresponding to what we may expect from variability within the group. In addition, the single shell of Sinetectula sp. non descr. from Indonesia combines features of $S$. egregia gen. et comb. nov. with $S$. nigricostata gen. et comb. nov., in line with our hypothesis that Sinetectula gen. nov. is a monophyletic group. Unfortunately, we couldn't trace any fossil record of Sinetectula gen. nov. to reveal the phylogentic pattern in time.

Further study will provide a definitive answer as to wether also Tritonidea castanea from the Persian Gulf and Pisania townsendi from Pakistan belong to Sinetectula gen. nov.

When at least six known species stay unrecognised as a group, then it is entirely possible that more than one species has escaped our attention. We therefore expect that additional species will become detected.

\section{Acknowledgements}

We thank all curators and staff members of the various institutes for their help to study the museum material, Yuri Kantor (A.N. Severtzov Institut of Ecology and Evolution, Russian Academy of Sciences, Moscow, Russia) for providing SEM photographs of the radula of S. egregia gen. et comb. nov. and helping us with good advice, Christine Zorn (Museum für Naturkunde, Berlin, Germany) for procuring images of the syntypes of Pisania naevosa, Jeanette and Scott Johnson (Kwajalein) for procuring images of living specimens of $S$. egregia gen. et comb. nov. and $S$. farinosa gen. et comb. nov., Yves Terryn (Belgium) for assistance and photography while visiting NHM(UK), Chris Vos (Belgium) for bibliographical help, Felix Lorenz (Germany), José Rosado (Mozambique), Andres Bonard (Argentina), Bruno Briano (Italy) and the late Rich Kelly (USA) for procuring additional material for study as well as two anonymous reviewers for thoroughly revising the manuscript and providing helpful advice.

\section{References}

Bouchet P., Héros V., Lozouet P. \& Maestrati P. 2008. A quarter-century of deep-sea malacological exploration in the South and West Pacific: where do we stand? How far to go? In: Héros V., Cowie R.H. \& Bouchet P. (eds) Tropical Deep-Sea Benthos 25: 9-40. Mémoires du Muséum national d'histoire naturelle 196.

Cernohorsky W.O. 1971. Indo-Pacific Pisaniidae (Mollusca: Gastropoda) and related buccinid genera. Records of the Auckland Institute and Museum 8: 137-167.

Cernohorsky W.O. 1975. Supplementary notes on the taxonomy of buccinid species of the subfamily Pisaniinae (Mollusca: Gastropoda). Records of the Auckland Institute and Museum 12: 175-211.

Dekker H. \& Orlin Z. 2000. Check-list of Red Sea Mollusca - Soortenlijst van Rode Zee Mollusca. Spirula 47 (supplement): 3-46.

Dekker H. \& Gemert L.J. van 2008. A new list with corrections to the shells pictured in "Red Sea Shells" (1984) by Doreen Sharabati - Een nieuwe lijst met verbeteringen voor de schelpen afgebeeld in "Red Sea Shells" (1984) van Doreen Sharabati. De Kreukel 44 (7-8): 123-136.

Fraussen K. \& Rosado J. 2011. The Cantharus group (Gastropoda: Buccinidae) on Almirante Leite Bank (Mozambique) with description of two new species and one new genus. Novapex 12 (3-4): 73-79. 
FRAUSSEN K. \& VERMEIJ G.J., Sinetectula gen. nov. (Buccinoidea: Pisaniidae)

Fraussen K. \& Stahlschmidt P. 2016. Revision of the Clivipollia group (Gastropoda: Buccinidae: Pisaniinae) with description of two new genera and three new species. Novapex 17 (2-3): 29-46.

Gould A.A. 1850. Descriptions of the shells brought home by the U.S. Exploring Expedition (continued). Proceedings of the Boston Society of Natural History 3: 151-156.

Kay E.A. 1965. Marine molluscs in the Cuming Collection, British Museum (Natural History) described by William Harper Pease. Bulletin of the British Museum (Natural History). Zoology. Supplement 1: $1-96$.

Kay E.A. 1979. Hawaiian Marine Shells. Reef and Shore Fauna of Hawaii. Section 4; Mollusca. Bishop Museum Press, Honolulu.

Keen A.M. 1958. Sea Shells of Tropical West America. Marine Mollusks from Lower California to Colombia. Stanford University Press, Palo Alto, California, USA.

Keen A.M. 1971. Sea Shells of Tropical West America. Marine Mollusks from Baja California to Peru. Stanford University Press, Palo Alto, California, USA.

Kilburn R.N., Marais J.P. \& Fraussen K. 2010. Buccinidae. In: Marais A.P. \& Seccoumbe A.D. (eds) Identification Guide to the Seashells of South Africa: 16-52. Centre for Molluscan Studies, Groenkloof.

Kurhe A.R., Rodríguez M.A. \& Suraywanshi G.D. 2014. Vertical distribution and diversity of gastropods molluscs from intertidal habitats of the Ratnagiri coast Maharashtra, India. International Research Journal of Natural and Applied Sciences 1 (6): 1-13.

López-Pérez R.A. 2013. Inventario de corales pétreos, anélidos, crustáceos decápodos, moluscos, equinodermos y peces óseos de los arrecifes coralinos de Guerrero y Oaxaca. In: Comisión nacional para el conocimiento y uso de la biodiversidad (CONABIO). Version 1.7. Occurrence dataset https://doi.org/10.15468/davjye [accessed via GBIF.org 8 Aug. 2020].

Martens E. von 1880. Mollusken. In: Moebius K., Richters F. \& Martens E. von (eds) Beiträge zur Meeresfauna der Insel Mauritius und der Seychelles: 179-353. Gutmann, Berlin.

Okutani T. 2000. Marine Mollusks in Japan. Tokai University Press, Tokyo.

Pease W.H. 1860. Descriptions of new species of Mollusca from the Sandwich Islands. Part II. Proceedings of the Zoological Society of London 28: 141-148.

Pilsbry H.A. \& Lowe H.N. 1932. West American and Central American mollusks collected by H.N. Lowe, 1929-1931. Proceedings of the Academy of Natural Sciences of Philadelphia 84: 33-144.

Ponder W.F. 1972. Notes on some Australian species and genera of the family Buccinidae (Neogastropoda). Journal of the Malacological Society of Australia 2 (3): 249-265.

https://doi.org/10.1080/00852988.1972.10673857

Reeve L.A. 1844a. Descriptions of new species of Tritons, collected chiefly by H. Cuming, Esq. in the Philippine Islands. Proceedings of the Zoological Society of London 12: 110-122.

Reeve L.A. 1844b. Conchologia Iconica: or, Illustrations of the Shells of Molluscous Animals. Vol. 2: Monograph of the genus Triton. Brothers Reeve, London. https://doi.org/10.5962/bhl.title.8129

Reeve L.A. 1846. Conchologia Iconica: or, Illustrations of the Shells of Molluscous Animals. Vol. 3: Monograph of the genus Buccinum. Brothers Reeve, London. https://doi.org/10.5962/bhl.title.8129

Robin A. 2008. Encyclopedia of Marine Gastropods. AFC and Conchbooks, Harxheim, Germany.

Schwengel J.S. 1950. Two Pacific species of Phos. The Nautilus 63 (3): 80-82.

Sharabati D. 1984. Red Sea Shells. KPI Limited, London. 
Shasky D.R. 1987. Cantharus fragarius (Wood, 1828) at Cocos Island. The Festivus 19 (4): 30-31.

Singer S.B. \& Mienis H.K. 1995. Shells from the Red Sea. Family: Buccinidae. La Conchiglia 27 (274): $22-29$.

Skoglund C. 1992. Additions to the Panamic Province gastropods (Mollusca) literature 1971 to 1992. The Festivus 24 (supplement): 1-8, 1-169. https://doi.org/10.5962/bhl.title.129425

Tomlin J.R. le B. 1926. On South African marine Mollusca, with descriptions of new species. Annals of the Natal Museum 5 (3): 283-301.

Tryon G.W. 1881. Manual of Conchology; Structural and Systematic. With Illustrations of the Species. Volume 3: Tritonidae, Fusidae, Buccinidae. Academy of Natural Sciences, Philadelphia, USA.

Verduin A. 1977. On a remarkable dimorphism of the apices in many groups of sympatric, closely related marine gastropod species. Basteria 41: 91-95.

Vermeij G.J. 1987. The dispersal barrier in the tropical Pacific: implications for molluscan speciation and extinction. Evolution 41: 1046-1058. https://doi.org/10.1111/j.1558-5646.1987.tb05875.x

Vermeij G.J. 2001. Innovation and evolution at the edge: origins and fates of gastropods with a labral tooth. Biological Journal of the Linnean Society 72: 461-508. https://doi.org/10.1006/bij1.2001.0524

Vermeij G.J. \& Bouchet P. 1998. New Pisaniinae (Mollusca, Gastropoda, Buccinidae) from New Caledonia, with remarks on Cantharus and related genera. Zoosystema 20 (3): 471-485.

Watters G.T. 2009. A revision of the western Atlantic Ocean genera Anna, Antillophos, Bailya, Caducifer, Monostiolum and Parviphos, with description of a new genus, Dianthiphos, and notes on Engina and Hesperisternia (Gastropoda: Buccinidae: Pisaniinae) and Cumia (Colubrariidae). The Nautilus 123 (4): 225-275.

Watters G.T. \& Finlay C.J. 1989. Revision of the Western Atlantic recent species of the genus Monostiolum Dall, 1904, and Bailya (Parabailya) new subgenus (Gastropoda: Buccinidae). The Veliger 32 (1): 47-59.

Wilson B. 1994. Australian Marine Shells. Prosobranch Gastropods, 2 (Neogastropods). Odyssey Publishing, Kallaroo, Australia.

Manuscript received: 7 August 2020

Manuscript accepted: 3 March 2021

Published on: 10 May 2021

Topic editor: Rudy Jocqué

Section editor: Thierry Backeljau

Desk editor: Kristiaan Hoedemakers

Printed versions of all papers are also deposited in the libraries of the institutes that are members of the EJT consortium: Muséum national d'histoire naturelle, Paris, France; Meise Botanic Garden, Belgium; Royal Museum for Central Africa, Tervuren, Belgium; Royal Belgian Institute of Natural Sciences, Brussels, Belgium; Natural History Museum of Denmark, Copenhagen, Denmark; Naturalis Biodiversity Center, Leiden, the Netherlands; Museo Nacional de Ciencias Naturales-CSIC, Madrid, Spain; Real Jardín Botánico de Madrid CSIC, Spain; Zoological Research Museum Alexander Koenig, Bonn, Germany; National Museum, Prague, Czech Republic. 